\title{
Transmission Electron Microscopy Study of the Neonatal Rat Tongue Mucosa Treated with Special Attention to the Bacteriae on the Epithelial Cell Membrane
}

\author{
Estudio al Microscopio Electrónico de Transmisión de la Mucosa de la Lengua de Rata Recién \\ Nacida con Atención Especial a las Bacterias en la Membrana Epitelial Celular
}

"Lara Cristina Picoli; "** Ruberval A. Lopes;"*Marisa Semprini; **Miguel Angel Sala \& *** Koichi Ogawa \& "Ii-sei Watanabe

PICOLI, L. C.; LOPES. R. A.; SEMPRINI, M.; SALA, M. A.; OGAWA, K. \& WATANABE, I. Transmission electron microscopy study of the neonatal rat tongue mucosa treated with special attention to the bacteriae on the epithelial cell membrane. Int. J. Morphol., 24(2):159-163, 2006.

SUMMARY: The epithelial cell surfaces of neonatal Wistar rat tongue mucosa were examined by transmission electron microscopic method. The tissues were fixed by modified Karnovksy solution and embedded in Spurr resin. Thin sections of 90 nm thickness were cut and examined in the Jeol 1010 transmission electron microscopy. It was revealed that the queratinized squamous epithelial cells of the tongue mucosa exposed to cadmium presented groupings of numerous bacteriae which are attached to the flat cell membrane surfaces. The coccus and bacillus are attached to the cell membrane in organized rows or at random, as clearly seen in the TEM images. At high magnification, the transmission electron microscopic images showed that bacteriae are attached by a fibrillar structures from each other and from epithelial cell membrane and bacteriae. The control group analysis demonstrated that the cell membrane didn't show the presence of bacteriae.

KEY WORDS: Epithelial cell; Tongue mucosa; Bacteria; Cadmium; Transmission electron microscopy.

\section{INTRODUCTION}

The characteristics of the tongue mucosa using scanning electron microscopic (SEM) methods are described in the tongue surface of rat (Yoshioka \& Muto, 1976; frog Rana cancrivora (Iwasaki \& Wanichanon, 1993); rat snake (Iwasaki et al., 1996a, 1996b); turtle (Iwasaki et al., 1996b) and mouse (Watanabe, 1989). Moreover, the tongue mucosa epithelial cells have been studied in human and animals by transmission (TEM) and scanning electron microscopy by Gibbins (1962); Apleton \& Tyldesley (1971); Arvidson (1976); Yoshioka \& Muto; Iwasaki \& Sakata (1985), Iwasaki \& Miyata (1985); Watanabe (1989); Iwasaki \& Wanichanon (1993) and Iwasaki et al. (1996a, 1996b).

Although few studies of the bacteria adhesion to the epithelial cell membranes were observed (Barnett, 1973; Brady et al., 1975; Kimura \& Pearsall, 1978; Howlett \& Squier, 1980; Douglas et al., 1981; McCourtie \& Douglas, 1981; Tokunaga et al., 1986, 1990; Watanabe et al., 1997; Motoyama et al., 1999.
This paper shows the presence of groupings of bacteriae and the adhesion of coccus and bacillus to the flat epithelial cell membrane of tongue dorsal mucosa of neonatal Wistar rat treated with cadmium employing transmission electron microscopy (TEM).

\section{MATERIAL AND METHOD}

Neonatal Wistar male rats were used, starting from the first day of postnatal life, whose mothers received 300 mg of chloride of cadmium for liter of water, throughout whole lactation. Control animals received a similar volume of water, without cadmium. The nestlings were sacrified through anesthetic overdose in the $21^{\circ}$ day, and were perfused using the modified Karnovsky solution, containing $2.5 \%$ glutaraldehyde, $2 \%$ paraformaldehyde in a $0.1 \mathrm{M}(\mathrm{pH} 7.3)$

\footnotetext{
* Department of Anatomy, Institute of Biomedical Sciences, University of São Paulo - USP, São Paulo, Brazil.

** Department of Morphology and Stomatology, School of Dentistry, Campus of Ribeirão Preto - USP, Brazil.

**** Department of Anatomy, School of Medicine, Fukuoka University, Fukuoka, Japan.
} 
sodium cacodilate buffer. Then, the tissues were fixed in the same solution for 12 hours at $4{ }^{\circ} \mathrm{C}$. The specimens were postfixed in $2 \%$ osmium tetroxide solution, rinsed in distilled water, and immersed in 2\% tannic acid solution for 1 hour at room temperature (Murakami,1974).

Then, the tissues were dehydrated in an increasing series of ethanol and propylene oxide and embedded in Spurr resin. The thick sections were made in Porter Blum ultramicrotome using glass knives and stained with toluidin blue solution for light microscopy analysis. For thin sections were used ultramicrotome Ultra-Cut Reichert with diamond knife. The ultrathin sections were mounted on 200 and 300 mesh grids, counterstained with uranyl acetate and lead citrate and examined in transmission electron microscopy Jeol, JSM1010 at $100 \mathrm{kV}$.

\section{RESULTS}

The epithelial cell surfaces of neonatal Wistar rat tongue mucosa examined by transmission electron microscope (TEM), revealed numerous polygonal cells of different forms and sizes. The keratinized epithelial cell layer of control animals showed a more regular disposition (Fig. 1). Several layers of flat cells are disposed containing cytoplasmic amorphous material. On the othar hand, the experimental animals presented flat cellular surfaces showing the grouping of bacteriae at random (Fig. 2). At high magnification, on the surface of cell membranes of experimental animals, the coccus and bacillus are clearly seen (Fig. 3).

The groupings of the bacteriae are constituted by numerous coccus and bacillus (Fig. 3). They are located on the flat epithelial cell surface of neonatal Wistar rat tongue mucosa. The groupings of bacteriae are usually attached on the microplicae of the epithelial cell membranes by a fibrillar structures from each other and from epithelial cell membrane and bacteriae (Fig. 3). The fine structure of bacteriae revelead a meshwork of fibrillar material around the surface (Fig. 3). The adhesion between the bacteria is also presented the fibrillar substances.

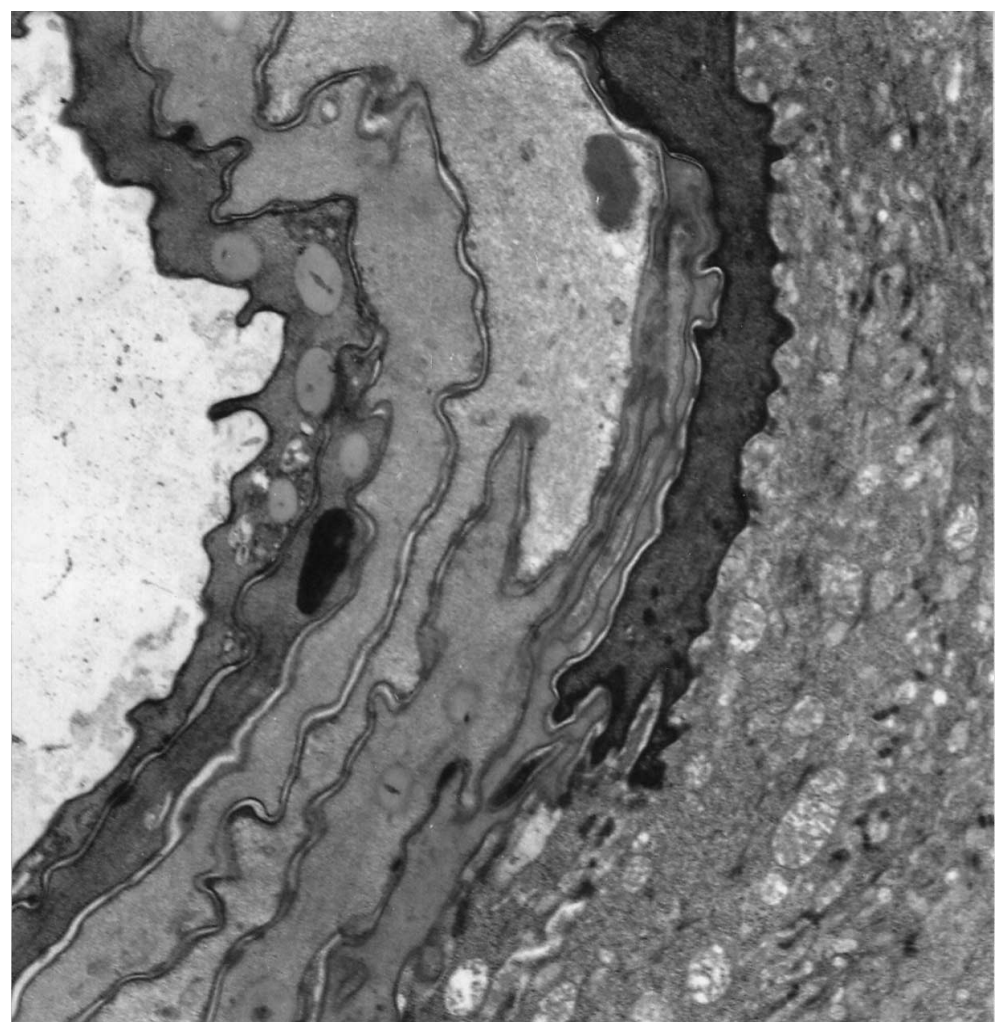

Fig. 1. TEM image of control neonatal Wistar rats tongue revealing the cell membrane surface. X 7500 .

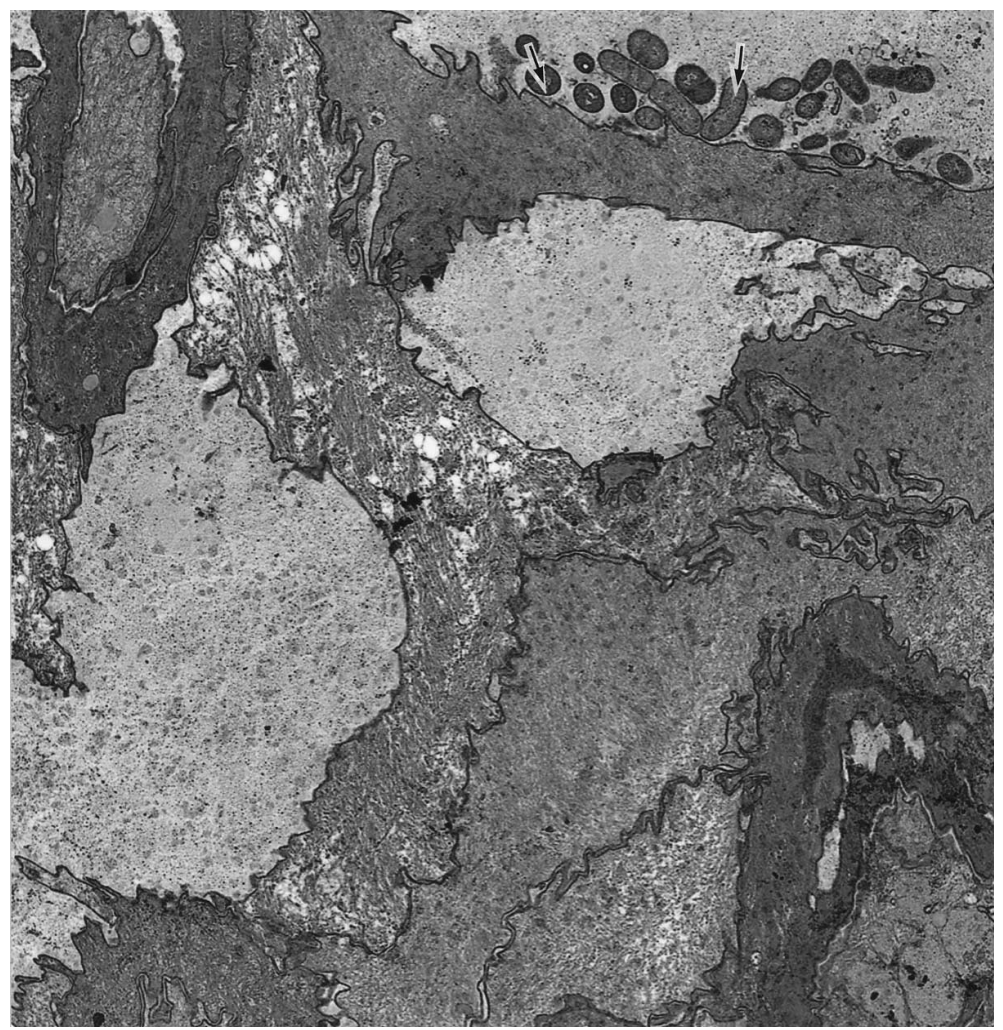

Fig. 2. Treated group. TEM image shows the flat surface of ephitelial cell revealing numerous bacteriae (arrows). X 3000. 


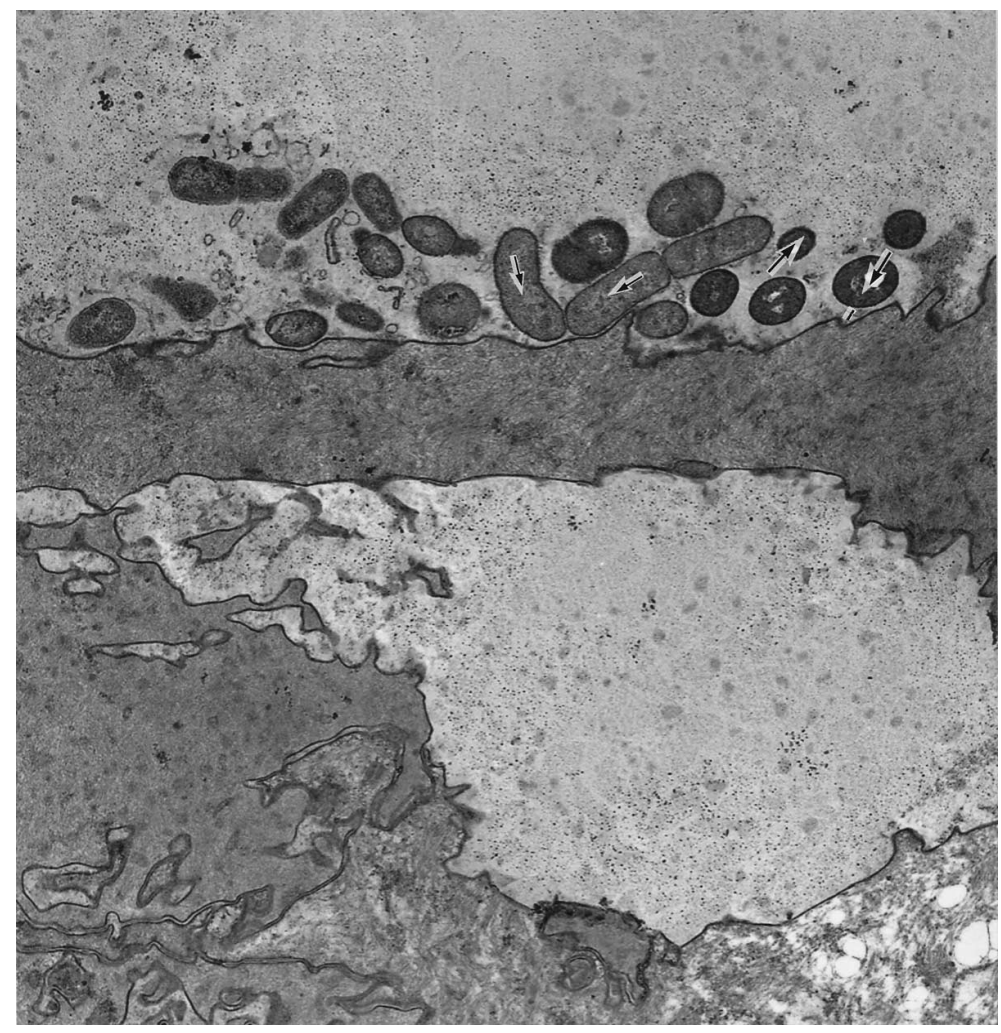

Fig. 3. Treated group. TEM image showing the adhesion of coccus (large arrows) and bacillus (small arrows). X 6000.

\section{DISCUSSION}

The epithelial cells showed numerous microplicae and these aspects are very similar to those reported by Iwasaki \& Sakata; Yoshioka $\&$ Muto and Watanabe. The epithelial cell membranes showed microplicae which are similar to those demonstrated previously by Arvidson; Iwasaki \& Sakata and Watanabe.

The samples of Wistar tongue dorsal mucosa exposed to cadmium presented several groupings of bacteria which were attached to the epithelial cell membranes. These characteristics were previously reported by Brady et al. and Watanabe et al. (1997) revealing that the bacteriae were attached to the epithelial cell membrane of rat tongue. Our results demonstrated the adhesion of the microorganisms on the surface of queratinized epithelial cell membranes by numerous fibrils structure. However, the penetration of the microorganisms depends on the localization and the epithelial cell features.

Barnett reported that the proteins of the streptococus may provide the adherence of the bacteria on the epithelial cell of the filiform and fungiform papillae.

Our results, the microrganisms on the epithelial cell surface of experimental animals were attached to host cells, and the adhesuion were made through an interaction between fine fibrillar material and the microplicae (Tokunaga et al., 1986,1990). The adhesion mechanisms involved in interaction of bacteria with the epithelium cell membrane must be elucidated using transmission electron microscopy images.

In our findings, the rat tongue of treated animals revealed microrganisms, usually in coccal form, attached to the surface of epithelial cells. The process of attachment of microrganisms to epithelial cell surface occurred through an interaction between fibrillar substance and the epithelial cell membranes as demonstrated in TEM images, as observed by Tokunaga et al. (1986,1990). Also, the ultrastructural findings about the adhesion of Candida albicans were noticed by Howlett \& Squier and Tokunaga et al. (1986) mentioning the mechanisms of interaction between Candida albicans and the epithelium cell surface. However, evidences suggested that the cell wall protein is the most important molecule for the Candida adhesion (Critchley \& Douglas, 1987; McCourtie \& Douglas, 1981, 1985). Our data confirmed that between bacteria surface and the epitelial cell membrane there are a complex network of filamentous materials clearly noted by transmission electron microscopy and in three-dimensional HRSEM images.

The scanning electron microscopic observations about the adhesion of Candida albicans were also described by Howlett \& Squier. The adhesion mechanisms involved in interaction of bacteria with the epithelium cell membrane have not been clarified. This paper do not intend to explain all aspects involved on the bacteria. Other papers using differents methods of electron microscopy must be developed in order to elucidate the adhesion of the microorganisms on the epithelial cell surfaces.

\section{ACKNOWLEDGEMENTS}

This paper was supported by CNPq. 
PICOLI, L. C.; LOPES. R. A.; SEMPRINI, M.; SALA, M. A.; OGAWA, K. \& WATANABE, I. Estudio al microscopio electrónico de transmisión de la mucosa de la lengua de rata recién nacida con atención especial a las bacterias en la membrana epitelial celular. Int. J. Morphol., 24(2):159-163-, 2006.

RESUMEN: A través de miscroscopía electrónica de transmisión se examinaron las células del epitelio de la mucosa lingual de ratas Wistar recién nacidas. Los tejidos fueron fijados en solución de Karnovksy modificada e incluidos en resina Spurr. Se obtuvieron delgados cortes de $90 \mathrm{~nm}$ y se observaron al microscopio electrónico de transmisión Jeol 1010.

Se encontró que las células epiteliales queratinizadas escamosas de la mucosa lingual expuestas al cadmio, presentaron grupos de numerosas bacterias las cuales estaban fijadas a las superficies de las membranas celulares. Los cocos y bacilos estaban fijados a las membranas celulares organizadas en pilas o columnas o al azar, como se aprecia claramente en las imágenes obtenidas a través de la microscopía electrónica de transmisión. Las imágenes mostraron que las bacterias estaban fijadas por estructuras fibrilares desde una a otra y desde las memebranas de las células epiteliales a las bacterias. El grupo control demostró que en las membranas celulares no era evidente la presencia de cadmio.

PALABRAS CLAVE: Célula epitelial; Mucosa lingual; Bacteria; Cadmio; Microscopía electrónica de transmisión.

\section{REFERENCES}

Apleton, J. \& Tyldesley, W. R. Observation on the ultrastructure of bucal epithelium of the rat. Arch. Oral Biol., 16:1071-88, 1971.

Arvidson, K. Scanning electron microscopy of fungiform papillae on the tongue of man and monkey. Acta Otolaryngol., 81:496-502, 1976.

Barnett, M. L. Adherence of bacteria to oral epithelium in vivo: electron microscopic observations. J. Dent. Res., 52:1160, 1973.

Brady, J. M.; Gray, W. A. \& Lara-Garcia, W. Localization of bacteria on the rat tongue with scanning and transmission electron microscopy. J. Dent. Res., 54:77782, 1975.

Critchley, I.A. \& Douglas, L.J. Isolation and partial characterization of an adhesion from Candida albicans. J. Gen. Microbiol., 133:629-36, 1987.

Douglas, L. J.; Houston, J. G. \& Mccourtie, J. Adherence of Candida albicans to human buccal epithelial cells after growth on different carbon souces. FEMS Microbiol. Lett., 12:241-3, 1981.

Gibbins, J. R. An electron microscopy study of the normal epithelium of the palate of the albino rat. Arch. Oral Biol., 7:287-95, 1962.

Howlett, J. A.\& Squier, C.A. Candida albicans: ultrastructure, colonization and invasion of oral epithelium. Infect. Immun., 29:252-60, 1980.
Iwasaki, S. \& Miyata, K. Studies on the lingual dorsal epithelium of the guinea pig by scanning electron microscopy. Okaj. Folia. Anat., 61:423-36, 1985.

Iwasaki, S. \& Sakata, K. Fine structure of the lingual dorsal surface of the Bull frog. Oka.j Folia. Anat, 61:437-50, 1985.

Iwasaki, S. \& Wanichanon, C. An ultrastructural study of the dorsal lingual epithelium of the crab-eating frog, Rana cancrivora. J. Morph., 215:89-100, 1993.

Iwasaki, S.; Yoshizawa, H. \& Kawahara, I. Three-dimensional ultrastructure of the surface of the tongue of the rat snake, Elaphe climacophora. Anat. Rec., 245:9-12, $1996 a$.

Iwasaki, S.; Asami, T. \& Wanichanon, C. Fine structure of the dorsal lingual epithelium of the juvenile hawksbill turtle, Gretmochelys imbriata bissa. Anat. Rec., 244:43743, $1996 b$.

Kimura, L. H. \& Pearsall, N. N. Adherence of Candida albicans to human buccal epithelial cells. Infect. Immun., 21:64-8, 1978.

McCourtie, J. \& Douglas, L.J. Relationship between cell surface composition of Candida albicans and adherence to acrylic after growth on different carbon sources. Infect. Immun., 32:1234-41, 1981.

McCourtie, J.\& Douglas, L.J. Extracellular polymer of Candida albicans isolation, analysis and role in adhesion. J. Gen. Microbiol., 131:495-503, 1985. 
Motoyama, A. A.; Watanabe, I.; Semprini, M.; Lopes, R. A.; Iyomasa, M. M. \& Mizusaki, C. I. Scanning electron microscopy of the rat tongue mucosa with special attention to the bacteria on epithelial cell membrane. Braz. Dent. J., 10(1):11-4, 1999.

Murakami, T. A revised tannin-osmium method for noncoated scanning electron microscope specimens. Arch. Histol. Jpn., 36:189-93, 1974.

Tokunaga, M.; Kusamichi, M. \& Koike, H. Ultrastructure of outermost layer of cell wall in Candida albicans observed by rapid-freezing technique. J. Electron. Microsc., 35:237-46, 1986.

Tokunaga, M.; Niimi, M.; Kusamichi, M. \& Koike, H. Initial attachment of Candida albicans cells to buccal epithelial cells. Mycopathologia, 111:61-6, 1990.

Watanabe, I. Papilas filiformes e fungiformes da mucosa lingual de camundongos. Estudo ao microscópio eletrônico de varredura. Arq. Anat. Antropol., 40:193-200, 1989.

Watanabe, I.; Kronka, M. C.; Koga, L.Y.; Utiyama, C.; Semprini, M. \& Konig Jr, B. Surface of interface epithelium-connective tissue of gingival mucosa of the Calomys callosus: a scanning electron microscopic study. Rev. Chil. Anat., 12:169-76,1994.

Watanabe, I.; Jin, C. \& Nagata, T. Field emission scanning electron microscopic study of the mouse lingual muco$\mathrm{sa}$, with special reference to adhesion of bacteria in the epithelia cell membranes. Braz. J. Morphol. Sci., 14:247$51,1997$.

Yoshioka, I. \& Muto, H. Surface structure of tongue, palate and buccal mucosa of rat by scanning electron microscopic study. Okaj. Folia. Anat., 52:277-312,1976.
Correspondence to: Prof. Dr. Ii-sei Watanabe, Departamento de Anatomia Instituto de Ciencias Biomédicas Universidade de São Paulo Av. Prof. Lineu Prestes, 2415 Cidade Universitária, CEP 05508-900 São Paulo - SP BRASIL

Phone: $+55-11-3091-7386$

Email-mail:watanabe@ic6.usp.br

Received: 27-01-2006

Accepted: 03-03-2006 
